\title{
Tracing surface and ground water with stable isotopes in a small permafrost research catchment
}

\author{
Liudmila Lebedeva ${ }^{1, *}$ \\ ${ }^{1}$ Melnikov Permafrost Institute SB RAS, Merzlotnaya 36 677010, Yakutsk, Russia
}

\begin{abstract}
The study aims at assessing groundwater contribution to the streamflow at the small permafrost Shestakovka river watershed in Central Yakutia. Water from stream, lakes, snow, rain, surface flow and suprapermafrost groundwater is characterized by specific isotopic signature. At least one third of the spring flood is formed by "old" preevent water as showed by mixing model based on stable isotopes as tracers. Presence of talik aquifers associated with sandy hills covered by pine forest suggests that talik groundwater could be an important source of streamflow at the small river basin in continuous permafrost.
\end{abstract}

\section{Introduction}

Seasonal flow in the thawing layer is considered to be the main source of streamflow in continuous permafrost zones. Although existence of taliks, layers of year-round unfrozen ground, is acknowledged, they are usually not accounted for in runoff generation research and in hydrological modelling approaches.

Stable isotopes are widely used as environmental tracers for assessment of water fluxes, travel and residence times. While there are many studies of isotopic composition of precipitation [1], ground ice [2], glaciers [3], and snow cover [4] there is little known about stable isotopes of surface and ground water in permafrost river basins in Siberia. Existing studies included estimation of residence time of groundwater spring in Central Yakutia [5] and analysis of isotopic composition of the Lena River near Yakutsk [6].

The presented study aims at assessing the river sources and their contribution to the streamflow at the small permafrost watershed in Central Yakutia. The study is based on field surveys for 2015-2017, the analysis of stable isotopes $\left(\delta \mathrm{D}\right.$ and $\left.\delta^{18} \mathrm{O}\right)$ and the application of a simple mixing model.

\section{Shestakovka research catchment}

The Shestakovka River watershed with $\left(170 \mathrm{~km}^{2}\right)$ is located $20 \mathrm{~km}$ south-west of Yakutsk within the erosion-denudational slope of the ancient accumulative plain with an absolute elevation of $150-280 \mathrm{~m}$. The permafrost thickness is $200-400 \mathrm{~m}$. The upper $40 \mathrm{~m}$ of the

\footnotetext{
* Corresponding author: lyudmilaslebedeva@gmail.com
} 
section are represented by quartz-feldspar sands with rare inclusions of silty sandy loam and loam. The climate is cold and dry with a mean annual air temperature of $-9.5^{\circ} \mathrm{C}$, and a precipitation of $240 \mathrm{~mm} /$ year (1950-2015). Annual Shestakovka river streamflow varies between 1.5 and $99 \mathrm{~mm} /$ year with mean value $24 \mathrm{~mm} /$ year (1951-2015). Fraction of spring flood (April and May) in the total river flow varies from 3 to $82 \%$ with a mean value of $50 \%$ / Dominant landscapes are pine forest (47\% of the watershed area), larch-birch forest (38\%), bogs (14\%) and lakes. Active layer (AL) thickness in the pine forest could reach 3-4 $\mathrm{m}$. Larch forests are characterized by cold permafrost with AL thickness up to $1 \mathrm{~m}$. Suprapermafrost talik aquifers are abundant phenomena at sandy gentle slopes covered by pine forests in the Shestakovka river watershed [7, 8]. Typically taliks were found in the depth interval from 2.5 to $10 \mathrm{~m}$. They could be up to $1 \mathrm{~km}$ long. It is roughly estimated that taliks occupy $20-25 \%$ of the Shestakovka river watershed. Talik groundwater contributes to the river that is confirmed by formation of aufeises in winter on the river terrace slopes.

\section{Methods}

In 2015, 2016 and 2017408 water samples were taken from river streams, lakes, snow, rain, surface flow and suprapermafrost groundwater in the Shestakovka River watershed and analysed for stable isotope composition in Stable Isotope Laboratory in the Alfred Wegener institute in Potsdam and in the Climate and Environmental Research Laboratory in Arctic and Antarctic Research Institute in St.Petersburg. Stable isotope values are expressed using the $\delta$ convention in per mil (\%o) units relative to Vienna Standard Mean Ocean Water.

Water sampling was performed daily during the spring flood and every 10-15 days during the summer. Water levels at talik aquifers, lakes, river were observed during the warm season. Water discharge at two gauging stations was measured along with stream water sampling.

A steady state form of mass balance equations were used to separate river discharge for spring floods in 2015, 2016 and 2017 into two flow components on the basis of endmember concentrations $[9,10]$ :

$$
\begin{gathered}
Q_{r}=Q_{1}+Q_{2} \\
C_{r} Q_{r}=C_{1} Q_{1}+C_{2} Q_{2}
\end{gathered}
$$

where $Q$ is discharge, $C$ is isotopic concentration, and the subscripts $r, 1$ and 2 refer to the river, first end-member and second end-member components, respectively. This method has been used successfully in different environments [11-16].

\section{Results}

Different water storages could be distinguished based on water isotopic composition (fig.1). Snow has the lightest isotopic composition that varies between $-230 \%$ and $275 \%$ in $\delta \mathrm{D}$ and between $-28 \%$ and $-37 \%$ in $\delta^{18} \mathrm{O}$. Rain water is on average most enriched in D $\left(-70 \% 0^{-}\right.$ $150 \%$ ) and in ${ }^{18} \mathrm{O}(-6 \%$-30\%o). River water and surface flow in bogs have the highest variation during the warm season. It is depleted $\left(-30 \% \delta^{18} \mathrm{O},-243 \%\right.$ oD) during snowmelt and enriched $\left(-17 \% \delta^{18} \mathrm{O},-144 \% \mathrm{DD}\right)$ at the end of the summer. The lightest stable isotope composition of stream water relates to period with highest contribution of snowmelt water. In 2015 these days coincide with spring flood peak discharges. In 2016 and 2017 these days were 2 and 5 days earlier than the peak discharge date accordingly. Intermittent surface flow during depressions occurring only in spring flood period has transitional composition 
between stream and snowmelt water. Water of three regularly sampled lakes is affected by evaporation. $\delta^{18} \mathrm{O}$ and $\delta \mathrm{D}$ in lake water vary from $-22 \%$ and $-185 \%$ in snowmelt period to $8 \%$ and $-94 \%$ in July and August respectively. Suprapermafrost talik groundwater has $\delta^{18} \mathrm{O}$ values between $-19 \%$ and $-24 \%$, $\delta \mathrm{D}$ values between $-150 \%$ and $-175 \%$. Isotopic composition of groundwater is very stable through the year.

Field surveys and the analysis of isotopic ratios showed that some surface flow occurs only in bogs. Subsurface flow could form in larch forests in seasonally thawing layers in July and August. Dry sandy deposits at some slopes in pine forests do not produce surface or shallow subsurface flow but have deeper flowpaths in talik aquifers.

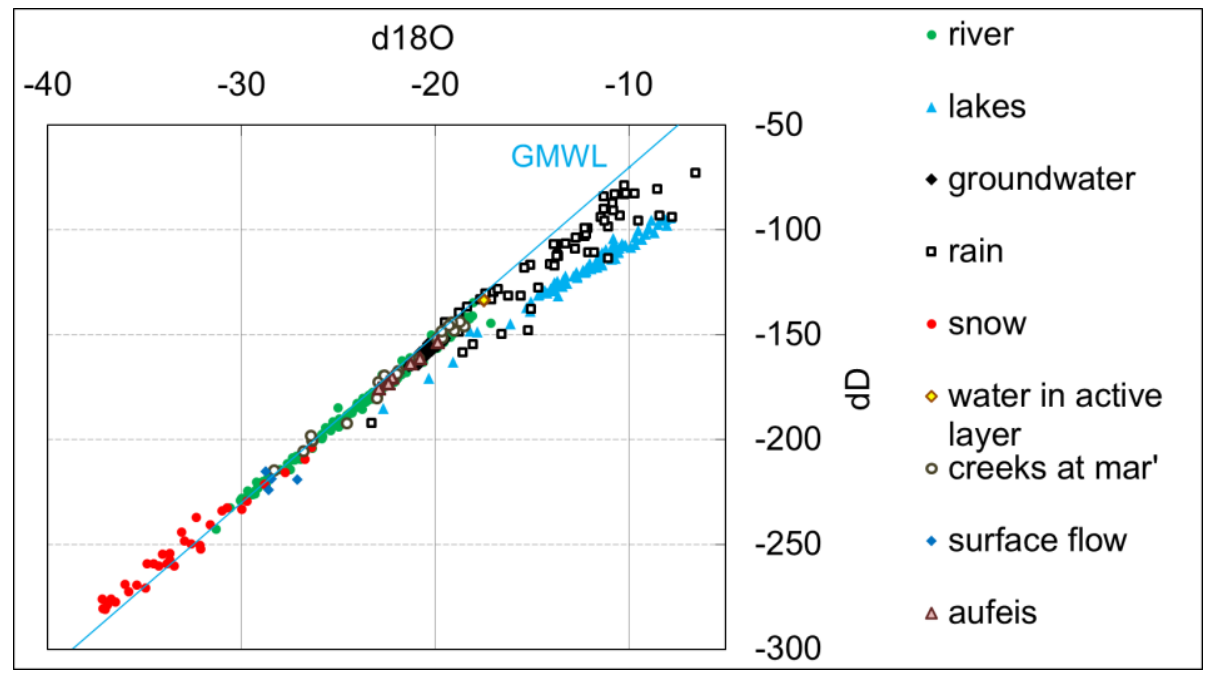

Fig. 1. $\delta^{18} \mathrm{O}-\delta \mathrm{D}$ diagram of different water reservoirs in the Shestakovka river basin.

Isotopic signature of "new" water relates to last before snowmelt samples of snow averaged across the watershed. Isotopic signature of "old" water is defined as isotopic composition of recent sample of the talik ground water. The results of the two-component mixing model (fig.2) showed that in 2015 snowmelt water contributed only $30-53 \%$ of streamflow while $47-70 \%$ of freshet was supplied by "old" water. In 2016 and 2017 "old" water contribution was $47-73 \%$ and $33-44 \%$ of the total spring flood discharge while snowmelt water stood for $27-53 \%$ and $56-67 \%$ of the freshet.

Suprapermafrost talik water is likely source of the pre-event "old" water. Significant role of groundwater is indirectly confirmed by delayed response of the Shestakovka River to precipitation. Annual flow depth has a high correlation coefficient with precipitation sum for three years, the current and two preceding year. Correlation coefficient between annual flow and precipitation for the current year or the sum of two years is lower. Monthly flow in summer is controlled by precipitation for sum of two months. Flow for the spring flood period correlates with sum of precipitation for one year - from June last till May and does not show high dependence on snow precipitation only. Even daily flow has higher correlation with precipitation for 12-17 days and very low correlation with precipitation of recent 1-7 days. This suggests that large and slow water storages in the basins are important factors in runoff generation. Taliks could potentially be a significant water source for the small rivers in permafrost environments that is not reflected in current process understanding and modelling approaches. 


\section{Conclusion}

In continuous permafrost in Central Yakutia suprapermafrost talik aquifers are found on gentle sandy slopes covered by pine forest. Taliks occupy $20-25 \%$ of the Shestakovka river watershed. Taliks are typically 50-1000 m long and 2-10 m deep. Shestakovka river streamflow has a delayed response to precipitation on daily, monthly, seasonal and annual time scale. Different water storages in the river basin are characterized by specific isotopic signature that allows using $\delta^{18} \mathrm{O}$ and $\delta \mathrm{D}$ isotopes as tracers. Two-component mixing model showed that at least one third of the Shestakovka river spring flood is formed by "old" water. All those findings lead to conclusion that talik groundwater could be an important source of streamflow at the small river basin in continuous permafrost.
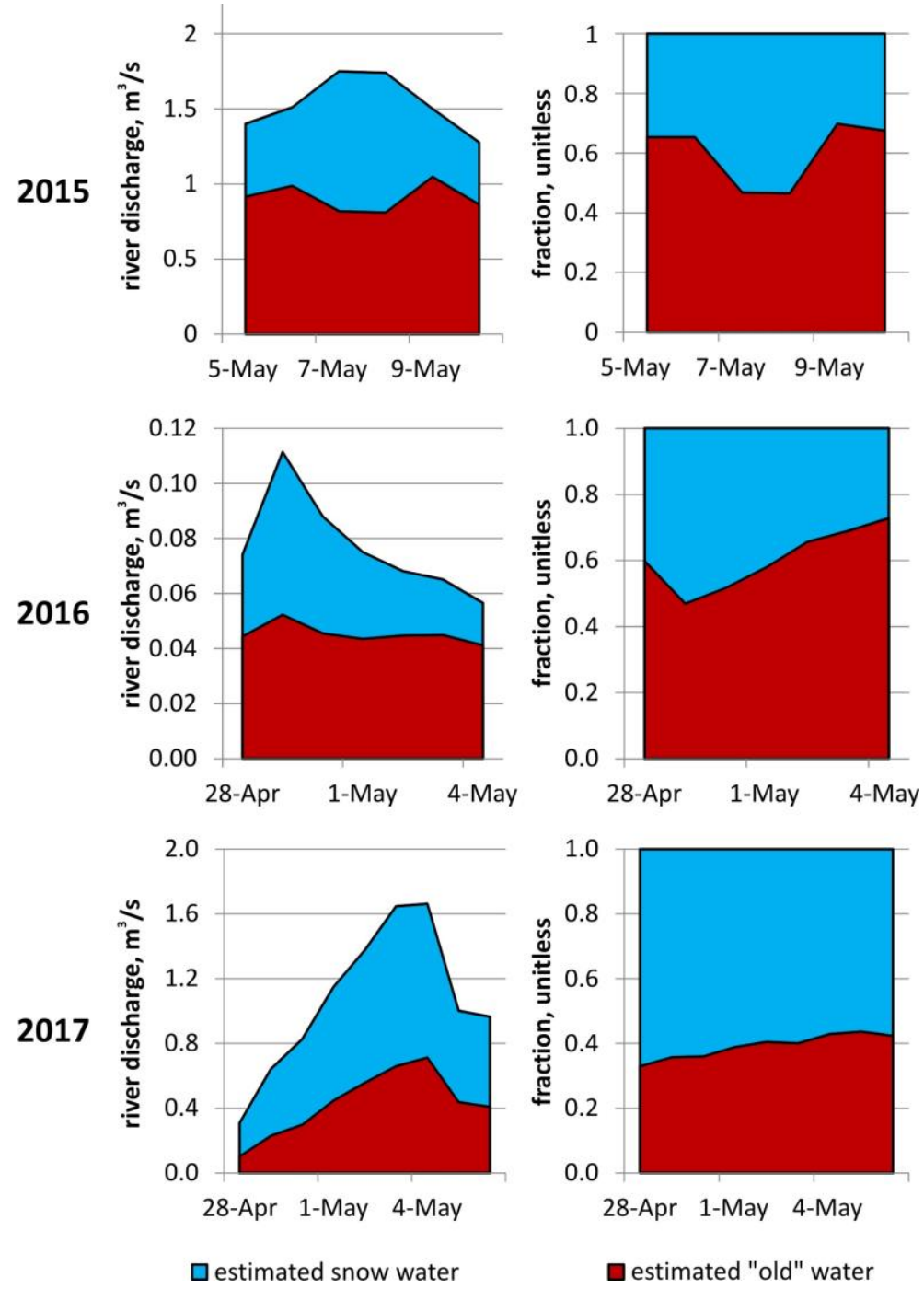

Fig. 2. Spring flood hydrograph separation at the Shestakovka river basin for 2015, 2016 and 2017. Graphs on the left correspond to absolute values in $\mathrm{m}^{3} / \mathrm{s}$, on the right - relative values of streamflow fraction. 
The study is partly supported by RFBR, projects No 17-05-00926, 17-05-00217, 17-05-01287 and 1845-140065.

\section{References}

1. T.S. Papina, N.S. Malygina, A.N. Eirikh, A.A. Galanin, M.N. Zheleznyak, Earth Cryosphere, 21 (2), 60-69 (2017)

2. T. Opel, H. Meyer, S. Wetterich, T. Laepple, A. Dereviagin, J. Murton, Permafrost and Periglac Process, 29 (3), 199-209 (2018)

3. N.A. Budantseva, B.R. Mavlyudov, Ju.N. Chizhova, Yu.K. Vasil'chuk, Ice and Snow, 56 (1), 20-28 (2016)

4. Y.K.Vasil'chuk, N.A.Budantseva, V.P.Shevchenko, A.P.Lisitzin, S.N.Vorobiov, S.N.Kirpotin, I.V.Krizkov, R.M.Manasypov, O.S.Pokrovsky, J.N.Chizhova, Doklady Earth Sciences, 471 (2), 1284-1287 (2016)

5. T. Hiyama, K. Asai, A.B. Kolesnikov, L.A. Gagarin, V.V. Shepelev, Environ. Res. Lett., 8, 035040 (2013)

6. A. Sugimoto, T.C.Maximov, Monitoring Isotopes in Rivers: Creation of the Global Network of Isotopes in Rivers (GNIR), IAEA-TECDOC-1673. Results of a Coordinated Research Project 2002-2006, 41-50 (2012)

7. A.V. Boitcov, Geocryology and underground water of the cryolithozone (2011)

8. L .Lebedeva, K. Bazhin, I. Khristoforov, 5th European Conference On Permafrost Book of Abstracts, 1030-1031 (2018)

9. N. Caine, J. of Hydrology, 112 89-101 (1989)

10. J.K. Sueker, J.N. Ryan, C. Kendall, R.D. Jarrett, Water Resources Research, 36 63-75 (2000)

11. J.P. McNamara, D.L. Kane, L.D. Hinzman, Water Resources Research, 33 1707-1719 (1997)

12. S. Carey, W. Quinton, Hydrology Research, 35 309-24 (2004)

13. F. Liu, M.W. Williams, N. Caine, Water Resources Research, 40 W09401 (2004)

14. L.E. Brown, D.M. Hannah, A.M. Milner, C. Soulsby, A.J. Hodson, M.J. Brewer, Water Resources Research, 42 W08404 (2006)

15. M. Dzikowski, S. Jobard, Hydrol. Process, 26 2724-2732 (2012)

16. P.J. Blaen, D.M. Hannah, L.E. Brown, A.M. Milner, Hydrol. Process, 28 3521-3538 (2014) 